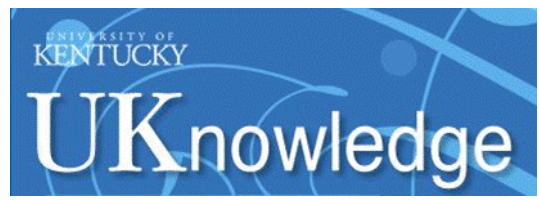

University of Kentucky

UKnowledge

Pharmacology and Nutritional Sciences Faculty

Publications

Pharmacology and Nutritional Sciences

$1-2017$

\title{
Cellular and Molecular Mechanisms Underlying Alcohol-Induced Aggressiveness of Breast Cancer
}

\author{
Yongchao Wang \\ University of Kentucky, yongchao.wang@uky.edu \\ Mei Xu \\ University of Kentucky, mxu222@uky.edu \\ Zun-Ji Ke \\ Shanghai University of Traditional Chinese Medicine, China \\ Jia Luo \\ University of Kentucky, jialuo888@uky.edu
}

Follow this and additional works at: https://uknowledge.uky.edu/pharmacol_facpub

Part of the Cancer Biology Commons, Pharmacology Commons, and the Substance Abuse and Addiction Commons

Right click to open a feedback form in a new tab to let us know how this document benefits you.

\section{Repository Citation}

Wang, Yongchao; Xu, Mei; Ke, Zun-Ji; and Luo, Jia, "Cellular and Molecular Mechanisms Underlying Alcohol-Induced Aggressiveness of Breast Cancer" (2017). Pharmacology and Nutritional Sciences Faculty Publications. 88.

https://uknowledge.uky.edu/pharmacol_facpub/88

This Article is brought to you for free and open access by the Pharmacology and Nutritional Sciences at UKnowledge. It has been accepted for inclusion in Pharmacology and Nutritional Sciences Faculty Publications by an authorized administrator of UKnowledge. For more information, please contact UKnowledge@lsv.uky.edu. 


\section{Cellular and Molecular Mechanisms Underlying Alcohol-Induced Aggressiveness of Breast Cancer}

Digital Object Identifier (DOI)

https://doi.org/10.1016/j.phrs.2016.12.005

Notes/Citation Information

Published in Pharmacological Research, v. 115, p. 299-308.

(C) 2016 Elsevier Ltd. All rights reserved.

This manuscript version is made available under the CC-BY-NC-ND 4.0 license https://creativecommons.org/licenses/by-nc-nd/4.0/.

The document available for download is the author's post-peer-review final draft of the article. 
Published in final edited form as:

Pharmacol Res. 2017 January ; 115: 299-308. doi:10.1016/j.phrs.2016.12.005.

\title{
Cellular and Molecular Mechanism Underlying Alcohol-induced Aggressiveness of Breast Cancer
}

\author{
Yongchao Wang ${ }^{1}$, Mei $\mathbf{X u}^{1}$, Zun-ji Ke ${ }^{2}$, and Jia Luo ${ }^{1,2, \#}$ \\ ${ }^{1}$ Department of Pharmacology and Nutritional Sciences, University of Kentucky College of \\ Medicine, Lexington, KY 40536 \\ 2Department of Biochemistry, Shanghai University of Traditional Chinese Medicine, Shanghai, \\ China 201203
}

\section{Abstract}

Breast cancer is a leading cause of morbidity and mortality in women. Both Epidemiological and experimental studies indicate a positive correlation between alcohol consumption and the risk of breast cancer. While alcohol exposure may promote the carcinogenesis or onset of breast cancer, it may as well enhance the progression and aggressiveness of existing mammary tumors. Recent progress in this line of research suggests that alcohol exposure is associated with invasive breast cancer and promotes the growth and metastasis of mammary tumors. There are multiple potential mechanisms involved in alcohol-stimulated progression and aggressiveness of breast cancer. Alcohol may increase the mobility of cancer cells by inducing cytoskeleton reorganization and enhancing the cancer cell invasion by causing degradation and reconstruction of the extracellular matrix (ECM). Moreover, alcohol may promote the epithelial-mesenchymal transition (EMT), a hallmark of malignancy, and impair endothelial integrity, thereby increasing the dissemination of breast cancer cells and facilitating metastasis. Furthermore, alcohol may stimulate tumor angiogenesis through the activation of cytokines and chemokines which promotes tumor growth. Additionally, alcohol may increase the cancer stem cell population which affects neoplastic cell behavior, aggressiveness, and the therapeutic response. Alcohol can be metabolized in the mammary tissues and breast cancer cells which produces reactive oxygen species (ROS), causing oxidative stress. Recent studies suggest that the epidermal growth factor receptor (EGFR) family, particularly ErbB2 (a member of this family), is involved in alcohol-mediated tumor promotion. Breast cancer cells or mammary epithelial cells over-expressing ErbB2 are more sensitive to alcohol's tumor promoting effects. There is considerable cross-talk between oxidative stress and EGFR/ErbB2 signaling. This review further discusses how the interaction between oxidative stress and EGFR/ErbB2 signaling contributes to the cellular and molecular events associated with breast

\#Correspondence author: Jia Luo, Department of Pharmacology and Nutritional Sciences, University of Kentucky College of Medicine, 132 Health Sciences Research Building, 1095 Veterans Drive, Lexington, Kentucky 40536. jialuo888@uky.edu; Tel: 859-323-3036; Fax: 859-257-0199.

Conflicts of interest

The authors declare that there are no conflicts of interest.

Publisher's Disclaimer: This is a PDF file of an unedited manuscript that has been accepted for publication. As a service to our customers we are providing this early version of the manuscript. The manuscript will undergo copyediting, typesetting, and review of the resulting proof before it is published in its final citable form. Please note that during the production process errors may be discovered which could affect the content, and all legal disclaimers that apply to the journal pertain. 
cancer aggressiveness. We also discuss the potential therapeutic approaches for cancer patients who drink alcoholic beverages.

\section{Graphical abstract}

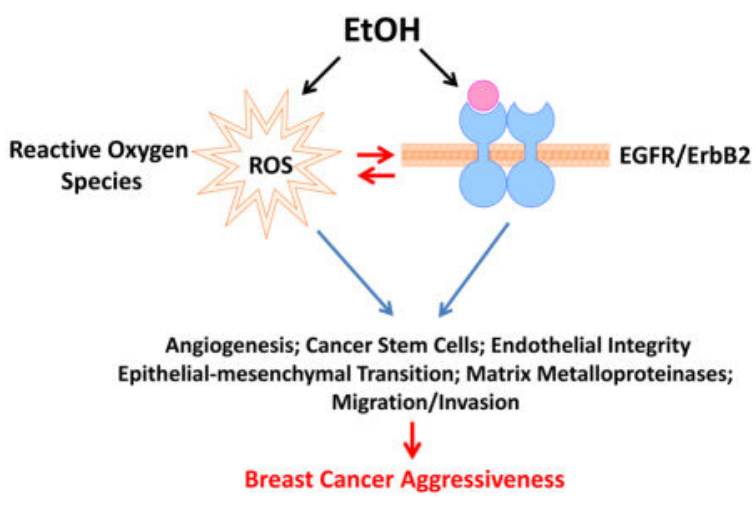

\section{Keywords}

Alcoholism; cancer stem cells; carcinogenesis; estrogen; HER2/ErbB2; oxidative stress

\section{Introduction}

Breast cancer is a leading cause of morbidity and mortality in women [1,2]. Although the exact etiology of breast cancer is unclear, nutrition and life style have been considered important contributing factors [3, 4]. Heavy alcohol consumption has devastating health effects and is associated with many maladies such as infectious diseases, cancer, digestive diseases, diabetes, neuropsychiatric diseases, cardiovascular disease, liver and pancreatic disease [5]. It is now well-established that alcohol consumption is a risk factor for breast cancer [6-13]. Upon careful evaluation, it appears that alcohol may not only increase the risk, but also promote the malignancy of existing mammary tumors; that is, alcohol may promote both onset/carcinogenesis and progression/prognosis.

For the onset/carcinogenesis of mammary tumors, there are several potential contributing mechanisms. First, alcohol exposure may cause DNA damage and gene mutation. Although alcohol per se is not a direct carcinogen, acetaldehyde, a product of alcohol metabolism, is a mutagen which can form adducts with protein and DNA, inducing gene mutation, DNA crosslinks and chromosomal aberrations [9, 14-18]. Alcohol dehydrogenase (ADH), a key enzyme of alcohol metabolism, is expressed in the human breast epithelial cells; therefore the human mammary tissue has the capacity to metabolize alcohol [9]. Due to limited ability to detoxify acetaldehyde in the mammary tissue, acetaldehyde accumulates for prolonged periods, which enhances its toxicity [9]. It is proposed that alcohol exposure induces mammary carcinogenesis through the production of acetaldehyde [19]. Second, alcohol may promote mammary carcinogenesis by altering circulating sex hormone levels. Sex hormones, such as estrogen, play an important role in the etiology of breast cancer. Perturbed estrogen levels and increased expression and activity of estrogen receptor a (ERa) are identified upon chronic alcohol consumption [9, 17, 20-23]. Third, alcohol-induced 
dysregulation of epigenetic regulation of gene expression, particularly abnormal DNA methylation may also contribute to mammary carcinogenesis, because epigenetic dysregulation is a key mechanism for tumor initiation and progression [9, 24]. Forth, alcohol may promote the carcinogenesis by disrupting the homeostasis of growth factors and nutrient status, such as IGF1 and vitamins [19, 25-27]. In addition to its carcinogenic effect, alcohol abuse is associated with advanced and invasive breast cancer [28-31], suggesting that alcohol may promote the progression of existing tumors and induce more aggressive phenotypes. Indeed, a number of recent experimental studies support this hypothesis and show that alcohol enhances the aggressiveness and malignancy of breast cancer [32-34]. Although alcohol-mediated carcinogenesis and progression/aggressiveness could share some common causes, distinct mechanisms may operate. A better understanding of these mechanisms is critical in developing effective therapeutic strategies for breast cancer patients who drink alcoholic beverages. This review will discuss the recent progress in this line of research.

Experimental studies clearly demonstrate that alcohol alters the behavior of breast cancer cells and changes them to more aggressive phenotypes. We will first review the effect of alcohol on cellular events and processes associated with cancer aggressiveness and malignancy, and then discuss the potential underlying cellular/molecular mechanisms.

\section{Alcohol-induced aggressiveness of breast cancer}

\subsection{Alcohol promotes migration/invasion, growth and metastasis of breast cancer cells}

Cancer metastasis is the spread of cancer cells to tissues and organs beyond where the tumor originated and the formation of new tumors. The metastatic cascade can be separated into three main processes: invasion, intravasation, and extravasation. The process of invasion involves the loss of cell-cell adhesion capacity which allows malignant tumor cells to dissociate from the primary tumor mass and invade the surrounding stroma. Intravasation is the invasion of cancer cells through the basal membrane into a blood or lymphatic vessel. This process enables cells to enter the circulatory system and metastasize to distant sites. The process of extravasation occurs when the tumor cells have arrived at the destination, they penetrate the endothelium and the basement membrane, forming new tumors.

Using Boyden chamber and wound healing assays, the data from our laboratory and others consistently show that alcohol enhances the migration of breast cancer cells [32, 33, 35-38]. Alcohol-induced mobility may result from the interaction with the extracellular matrix (EMC) and reorganization of the cytoskeleton system $[38,39]$. Alcohol also increases the invasive potential of breast cancer cells [37, 40-42]. The increased invasion is likely mediated by the enhanced ability of breast cancer cells to degrade the EMC, in which matrix metalloproteinases (MMPs) play an important role [40, 41]. Alcohol-stimulated migration/ invasion is further demonstrated in a 3-dimension (3-D) Matrigel system [32, 33]. The aggressive breast cancer cells have a property to grow to scattering spheroids in the 3-D culture system. We show that alcohol exposure significantly increases the spreading of breast cancer cells in this 3-D system. More importantly, after chronic exposure to alcohol, less aggressive breast cancer cells are transformed into a more aggressive phenotype which is demonstrated by the scattering spheroids in the 3-D culture system [32, 33]. In some 
studies, alcohol is shown to promote the growth of breast cancer cells both in vitro and in vivo [21-23, 43-45]. Alcohol-induced increase in the growth of breast cancer cells may result from either enhanced cell proliferation or promotion of survival. Animal studies confirm that alcohol consumption not only promotes the growth but also the metastasis of breast cancer cells to the lung and colon in mice [32, 33, 43, 44]. MMTV-neu transgenic mice are extensively used for the study of the tumorigenesis and progression of breast cancer. These mice express neu oncogene (homology to human ERBB2) under the transcriptional control of the mouse mammary tumor virus promoter/enhancer and develop spontaneous mammary tumors. Chronic alcohol consumption significantly promotes the metastasis of breast cancer cells to the lung and colon (Fig. 1) [33].

\subsection{Alcohol disrupts extracellular matrix (ECM), endothelial integrity, and promotes epithelial- mesenchymal transition (EMT)}

One of the key functions of MMPs is to degrade the ECM, a critical step for the intravasation and extravasation. MMPs play an important role in the malignancy of mammary tumors [46]. MMP2 and MMP9 are two typical collagenases secreted by tumor cells or stromal cells that catalyze the destruction of the surrounding ECM. It has been demonstrated that alcohol can promote the degradation of the ECM by activating MMPs. Etique et. al. [47] show that alcohol stimulates the secretion of MMP2 and MMP9 from breast cancer cells. In our studies, alcohol activates MMP2 in breast cancer cells by promoting the cleavage of the pro-enzyme and transferring to an active enzyme. Knocking down of MMP2 with small interference RNA or selective inhibitors partially blocks alcoholstimulated cell invasion [41]. Interestingly, alcohol can also stimulate the secretion and activation of MMP2 from stromal fibroblast cells which are a major cell type expressing MMP2 [40]. Moreover, the activation of fibroblast-derived MMP2 significantly contributes to the invasive phenotype of breast cancer induced by alcohol exposure [40]. Different from the report by Etique et al. [47], our studies show that alcohol selectively activates MMP2 but not MMP9 in mammary epithelial cells or fibroblasts [40, 41].

Another potential mechanism for alcohol promotion of cancer metastasis is to disrupt the endothelial integrity which facilitates the intravasation and extravasation. Alcohol-induced disruption of endothelial integrity is evident by the decrease of electric resistance across the endothelial monolayer and the appearance of an intercellular gap among endothelial cells [48]. The effect of alcohol is reversible once alcohol is removed. The disruption of the endothelial monolayer integrity was associated with an increased invasion of cancer cells through the endothelial monolayer. It appears the alcohol-induced disruption of endothelial integrity is caused by damaged adherens junctions resulting from the endocytosis of VEcadherin [48]. The epithelial-mesenchymal transition (EMT) is a developmental program but also plays an important role in cancer progression and metastasis. Studies suggest that alcohol can promote EMT phenotypic change and enhance aggressiveness of breast cancer. For example, vimentin, as a marker of mesenchymal cells or cells undergoing EMT, is upregulated by alcohol in breast cancer cells; conversely, E-cadherin, a hallmark for epithelial cells, is downregulated in breast cancer cells [49]. Other characteristics of EMT, such as increased expression of MMPs (MMP2, MMP7 and MMP9) and decreased expression of $a-, \beta-$, and $\gamma$-catenin are observed in breast cancer cells following alcohol 
exposure [36, 41, 49]. Snail is a key regulator of EMT and alcohol increases the expression and phosphorylation of Snail through stimulating EGFR signaling [49]. Together, these results suggest that alcohol may induce the EMT in breast cancer cells.

\subsection{Alcohol enhances tumor angiogenesis}

Angiogenesis in tumor tissues is an essential process for cancer growth and metastasis. Several studies consistently show that alcohol promotes tumor angiogenesis $[39,43,44,50$, 51]. A number of mechanisms have been proposed for alcohol-induced angiogenesis; these include enhanced endothelial cell proliferation and migration, promotion of cancer/ endothelial cell interaction and alterations of tumor microenvironment. An in vitro study shows that alcohol can directly target endothelial cells and cause actin filament reorganization, resulting in enhanced migration and tube formation of endothelial cells [39]. Using a 3-D endothelial cell/breast cancer cell co-culture system, we show that alcohol significantly increases the angiogenesis in the presence of cancer cells [43, 44]. The effect of alcohol is likely mediated by the stimulation of vascular endothelial growth factor (VEGF) and monocyte chemoattractant protein-1 (MCP-1) signaling. VEGF is a key regulator of angiogenesis. Alcohol upregulates the expression of VEGF and its receptor Flt-1 in mice; inhibiting VEGF-mediated signaling partially blocks alcohol-stimulated angiogenesis and tumor growth [44, 51]. MCP-1, also called chemokine (CC motif) ligand 2 (CCL2), is a proinflammatory chemokine, acting as a potent chemoattractant for monocytes and macrophages. Alcohol increases expression of MCP-1 and its receptor CCR2 in both mammary tumor tissues and breast cancer cells in vitro and in vivo [43]. CCR2 antagonist significantly inhibits alcohol-induced tumor angiogenesis and mammary tumor growth in mice [43].

\subsection{Alcohol increases the cancer stem-like cells (CSCs) population in breast cancer cells}

Breast cancers display considerable phenotypic and genetic heterogeneity. Cancer stem cells (CSCs), a subpopulation of cancer cells with self-renewal and differentiation capacity, play an important role in tumor initiation, progression, metastasis, recurrence, and therapy resistance $[52,53]$. The recent evidence from both in vitro and in vivo studies suggests that alcohol may increase the CSC population in breast cancer. We show that alcohol exposure causes a drastic increase in the CSC population and mammosphere formation in breast cancer cells overexpressing ErbB2 and in MMTV-neu mice (Fig. 2) [33]. In breast cancer cells with low levels of ErbB2, the CSC population is relatively small. These cells are relatively insensitive to acute alcohol exposure. However, long term treatment of alcohol also significantly increases the CSC population in these cells, which is accompanied by an increase in cell migration/invasion, anchorage-independent colony formation and scattering spheroids in a 3-D Matrigel system [32]. The findings are confirmed by the animal studies which show that chronic alcohol exposure increases CSCs in the mammary tumors of MMTV-neu transgenic mice [33]. 


\section{Cellular and molecular mechanisms underlying alcohol-induced cancer aggressiveness}

\subsection{Role of oxidative stress in alcohol-promoted breast cancer aggressiveness}

\subsubsection{Alcohol-induced reactive oxygen species (ROS) and oxidative stress in} mammary tissues and breast cancer cells-Excessive ROS accumulation and oxidative stress have been proposed as important mechanisms for mammary carcinogenesis and aggressiveness [54]. Alcohol-induced ROS and oxidative stress may be mediated by alcohol metabolism, damaged mitochondria, and an antioxidant response [55]. Alcohol is first oxidized to acetaldehyde in cytosol by alcohol dehydrogenase (ADH). Acetaldehyde is transported into the mitochondria and rapidly metabolized to acetate by aldehyde dehydrogenase 2 (ALDH2). In the mitochondria, acetate is converted to acetyl-CoA, which enters the citric acid cycle for ultimate oxidization. In both ADH and ALDH2 catalyzed reactions, $\mathrm{NAD}^{+}$, is used as an electron carrier to form $\mathrm{NADH}$, which is eventually transported into the mitochondria for ATP production. Depending on oxygen supply and the demand of ATP, NADH may not be efficiently oxidized, which causes electrons to be diverted to form ROS, causing oxidative stress [55]. During chronic alcohol consumption or in tissues that lack ADH, cytochrome P450 2E1 (CYP2E1) is induced to engage in alcohol metabolism, which concomitantly oxidizes NADPH to generate ROS. Alternatively, alcohol can activate NADPH oxidase (NOX) which produces ROS [56]. Alcohol-metabolizing enzymes such as cytochrome CYP2E1, ADH and xanthine oxidoreductase (XOR), and NOX are expressed in mammary tissues and breast cancer cells, indicating alcohol can be metabolized in mammary tissues [57-63].

ROS mainly comprises four species including superoxide anion, hypochlorite ion, hydroxyl radicals, and hydrogen peroxide. They are highly active and interact with lipid, protein, and DNA. Using electron spin resonance (ESR), we demonstrate that alcohol is able to generate a whole spectrum of ROS in mammary epithelial cells and breast cancer cells [38, 64]. Alcohol also promotes ROS production and oxidative stress in breast cancer-associated stromal fibroblasts [65]. It appears that CYP2E1 is involved in alcohol-induced ROS production in mammary epithelial cells; the alcohol-induced ROS in turn activates the epidermal growth factor receptor (EGFR) [66]. Other evidence shows that alcohol exposure may cause oxidative stress by down-regulation of detoxification enzymes in mammary epithelial cells, which results in decreased clearance of ROS [67].

\subsubsection{The role of ROS in alcohol-induced aggressiveness of breast cancer} cells-ROS is involved in alcohol-stimulated migration/invasion of breast cancer cells, because scavenging alcohol-induced ROS production by antioxidants significantly inhibits alcohol-induced migration and invasion [38, 41, 64]. ROS also plays a role in alcoholinduced MMP2 activation; antioxidants abrogate alcohol-induced MMP2 activation and inhibit the alcohol-stimulated invasion in mammary epithelial cells overexpressing ErbB2 [41, 68]. It appears that ROS mediates alcohol-induced breast cancer cells/ECM interaction and cell mobility. Cyanidin-3-glucoside (C3G), an anthocyanin present in many vegetables and fruits, is a potent natural antioxidant. We show that $\mathrm{C} 3 \mathrm{G}$ decreases alcohol-mediated cell 
adhesion to the ECM as well as the amount of focal adhesions and the formation of lamellipodial protrusion [38].

It is well established that ROS promotes EMT in mammary epithelial or breast cancer cells through diverse mechanisms [69, 70]. It is suggested that the activation of EGFR is involved in alcohol-promoted EMT [49] and alcohol may activate EGFR through intracellular ROS accumulation [66]. However, more direct evidece is required to draw a conclusion regrading the role of ROS in alcohol-promoted EMT.

ROS is long known for being involved in tumor angiogenesis [54, 71-74]. It is generally accepted that low levels of ROS promote angiogenesis whereas high levels of ROS may have the opposite effect. ROS regulation of angiogenesis is mainly mediated by VEGF signaling $[75,76]$. But ROS can also promote angiogenesis in a VEGF independent manner [77, 78]. We have previously shown that alcohol-induced ROS can directly promote the tube formation of endothelial cells [39]. We have also demonstrated that alcohol promotes angiogenesis in mammary tumors by stimulating MCP-1 signaling [43] and it is likely that alcohol-induced activation of MCP-1 is mediated by ROS [79].

In addition to promoting angiogenesis, alcohol-induced ROS may disrupt endothelial integrity, consequently increasing the permeability of blood vessels. We demonstrate that alcohol causes a reversible disruption of the endothelial barrier and an enhanced invasion of cancer cells through the endothelial monolayer [48]. Vascular endothelial cadherin (VEcadherin), a major component of endothelial adherens junctions, plays many functional roles in regulating endothelial barrier integrity. VE-cadherin is linked to the actin cytoskeleton through $\beta$ - and $\alpha$-catenin. The stabilization of the cadherin/catenin complex maintains endothelial integrity and inhibits tumor cell intravasation and extravasation. We show that alcohol inhibits VE-cadherin/ $\beta$-catenin association and disrupts the endothelial barrier [48]. Since ROS can cause phosphorylation of the VE-cadherin and thereby result in disassembly of VE-cadherin/catenin complex and the breakdown of intercellular connections [80-82], the effect of alcohol on endothelial integrity may be mediated by ROS production.

\subsection{Role of epidermal growth factor receptor (EGFR) family in alcohol-promoted breast cancer aggressiveness}

3.2.1. The EGFR and ErbB2 signaling pathways in breast cancer-The EGFR family is comprised of four structurally similar receptors including EGFR (ErbB1 or HER1), ErbB2 (HER2), ErbB3 (HER3) and ErbB4 (HER4) [83, 84]. They are type I transmembrane kinase receptors, which upon ligand binding in the extracellular domain, undergo dimerization and subsequent trans-phosphorylation in the intracellular domain. EGFR and ErbB2 receive particular attention in the context of breast cancer etiology and therapy because of their frequent overexpression and hyperactivation in breast carcinomas [83]. Overexpression of EGFR and ErbB2 is associated with malignant breast cancers, increased metastasis, and poor prognosis [84-88].

EGFR is activated by a number of ligands including EGF, amphiregulin, transforming growth factor alpha (TGFa), neuregulin $2 \beta$, betacellulin, heparin-binding EGF-like growth factor, and epiregulin $[84,89]$. So far there is no identified ligand for ErbB2; the activation 
of ErbB2 is mediated through heterodimeric partners, e.g., EGFR, ErbB3 ErbB4 [85]. Upon activation, EGFR and ErbB2 trigger several important signaling cascades that play a key role in the carcinogenesis and aggressiveness of breast cancer, such as MAPK, PI3K/AKT/ mTOR, Src, JAK/STAT3, PLC- $\gamma /$ PKC and GSK3 $\beta / \beta$-catenin [84, 88, 90-93]. The activation of these signaling cascades frequently promotes the proliferation, migration/invasion, growth, and metastasis of breast cancer [84].

\subsubsection{EGFR and ErbB2 signaling in alcohol-promoted aggressiveness of} breast cancer-It has been proposed that EGFR may mediate some of alcohol's tumor promoting effects [94]. Alcohol stimulates the phosphorylation of EGFR in mammary epithelial cells [66]. Snail, a transcriptional activator of EMT markers, is upregulated by alcohol in an EGFR-dependent manner [49]. Alcohol-induced migration of breast cancer cells is blocked by AG1478, an EGFR inhibitor [49]. Together, the evidence indicates that the activation of EGFR is involved in alcohol-promoted aggressiveness of breast cancer. There are several potential mechanisms underlying alcohol activation of EGFR; these include stimulation of EGFR phosphorylation by ROS, an increase in the expression of ligands for EGFR, and inhibition of phosphatases that regulate the dephosphorylation of EGFR [94].

More studies indicate the interaction between alcohol and ErbB2. Generally, there is a positive correlation between the expression level of ErbB2 and the sensitivity of breast cancer cells to alcohol-elicited migration/invasiveness. In a study we investigated the effect of alcohol on various breast cancer cell lines [35, 64]. For all human breast cancer cells and mammary epithelial cells examined, alcohol drastically increased the migration/invasion of cells overexpressing ErbB2, but only had a modest or little effect on cells with low ErbB2 expression. For breast cancer and mammary epithelial cells that are less responsive to alcohol, artificial overexpression of ErbB2 enhances their sensitivity to alcohol and potentiates alcohol-stimulated cell migration/invasion [64]. Alcohol up-regulates the expression of ErbB2, ErbB3 and ErbB4, but not ErbB1 in human breast cancer cells (T47D) [35]. Heregulin $\beta 1$ (ligand for ErbB3 and ErbB4) synergizes the alcohol-stimulated invasion of T47D [35]. Knocking down ErbB2 with an anti-sense oligonucleotide eliminates heregulin $\beta 1$ - and alcohol-promoted cell migration/invasion [35], supporting the conclusion that ErbB2 is involved in alcohol-stimulated migration/invasion of breast cancer cells. The enhanced sensitivity of breast cancer cells overexpressing ErbB2 may be mediated by alcohol-induced activation of ErbB2. We show that alcohol stimulates the phosphorylation of ErbB2 and its interaction with downstream effectors, such as cSrc and FAK (Fig. 3) [37].

In addition to migration/invasion, alcohol-induced MMP2 activation is also dependent on the expression of ErbB2 [41]. Both clinical and experimental data suggest that ErbB2 may regulate MMP production in breast cancer cells $[41,95]$. The activation of ErbB2 signaling increases MMP2 and MMP9 production through p38 MAPK and PI3K pathways [41]. Alcohol drastically activates MMP2 in mammary epithelial cells that over-express ErbB2, but has little effect on cells with low ErbB2 expression [41]. Furthermore, alcohol-induced interaction of breast cancer cells with the ECM, such as cell adhesion to the fibronectin, is also likely mediated by ErbB2 [37, 38]. The in vitro observation is supported by animal studies which show that chronic alcohol consumption enhances ErbB2 signaling in MMTV- 
neu mice and promotes the metastasis of breast cancer cells to the lung and colon (Fig 1) [33]. In addition, one study investigates the effect of prenatal alcohol exposure on the development of mammary glands and tumorigenesis in MMTV-neu mice. The results indicate that prenatal alcohol exposure alters the development of mammary glands and increases multiplicity of breast tumors with high expression of neu (ERBB2) [96].

ErbB2 also plays an important role in the alcohol-induced increase of CSC populations [33]. Alcohol exposure causes a drastic increase in the CSC population and mammosphere formation in breast cancer cells overexpressing ErbB2, but it has a modest effect on breast cancer cells expressing low levels of ErbB2 [33]. Consistently, alcohol consumption increases the CSC population and ErbB2 phosphorylation in the mammary tumors of MMTV-neu mice [33]. Both in vitro and in vivo studies indicate that alcohol significantly increases the phosphorylation of ErbB2 in breast cancer cells and mammary epithelial cells expressing high levels of ErbB2, but has little effect on cells with low levels of ErbB2 [33, 37, 64]. Together, these studies confirm the idea that alcohol induces ErbB2 activation and results in more aggressive neoplastic behavior.

\subsubsection{Down-stream signaling of EGFR and ErbB2 in alcohol-induced aggressiveness of breast cancer-As discussed above, a number of signaling} cascades down-stream of EGFR and ErbB2 may be involved in alcohol-induced aggressiveness of breast cancer, such as MAPK, PI3K/AKT/mTOR, Src, JAK/STAT3, PLC$\gamma / \mathrm{PKC}$ and GSK3$\beta / \beta$-catenin. Alcohol activates three members of MAPKs, namely, extracellular signal regulated kinase (ERK), c-Jun NH2 terminal protein kinase (JNK1/2) and p38 mitogen-activated protein kinase (p38 MAPK) in an ErbB2-dependent manner [64]. Only the selective inhibitors for JNK1/2 and p38 MAPK but not for PI3K and ERK inhibits alcohol-induced migration/invasion of breast cancer cells overexpressing ErbB2, indicating that JNK1/2 and p38 MAPK are involved in alcohol-promoted aggressiveness [64].

To further analyze the contribution of p38 MAPK to alcohol-promoted aggressiveness of breast cancer, we examined the effect of alcohol on p38 MAPK isoforms. So far, there are four $\mathrm{p} 38$ MAPK isoforms, $\mathrm{p} 38 \mathrm{a}, \mathrm{p} 38 \beta, \mathrm{p} 38 \gamma$ and $\mathrm{p} 388$. We show that alcohol selectively activates p38 $\gamma$ but not other isoforms in an ErbB2-dependent manner [32]. p38 $\gamma$ is particularly implicated in breast cancer progression and aggressiveness [97]. We show that p38 $\gamma$ is down-stream of ErbB2 because inhibition of ErbB2 abolishes alcohol-induced activation of $\mathrm{p} 38 \gamma$ and its interaction with the substrate, SAP97/DLG. SAP97/DLG is a scaffold protein and is involved in cell migration $[98,99]$. Moreover, the activation of ErbB2/p38 $\gamma / \mathrm{SAP} 97 / \mathrm{DLG}$ axis appears to mediate an alcohol-induced increase in migration/ invasion as well as CSC because blocking ErbB2 or p38 $\gamma$ significantly inhibits alcoholstimulated migration/invasion and increases CSC population [32].

RhoC, a member of Rho family of GTPase, has been suggested to enhance cell mobility and metastasis through the degradation and reconstruction of the ECM and induction of angiogenic factors [100-102]. Our results show that RhoC is a downstream effector of ErbB2 and $\mathrm{p} 38 \gamma$. The alcohol-induced activation of $\mathrm{p} 38 \gamma$ upregulates RhoC levels by promoting RhoC stability which results in enhanced migration/invasion [32]. 
FAK is a component of focal adhesions and regulates the formation of the focal complex. ErbB2/ErbB3 signaling has been reported to activate FAK, which leads to oncogenesis and invasiveness of breast cancer [103]. In addition, it has been suggested that FAK may regulate the activity of p38 MAPK and JNKs [104, 105]. We show that alcohol-induced activation of ErbB2 causes the phosphorylation of FAK (Y861) and cSrc (Y216), and promotes the interaction among them in breast cancer cells overexpressing ErbB2 (Fig. 3) [37].

Functionally, active FAK promotes cell adhesion to fibronectin, an important component of the ECM. AG825, an inhibitor for ErbB2, inhibits ErbB2 phosphorylation and its association with FAK, blocking alcohol-promoted formation of focal adhesions [37].

GSK3 $\beta / \beta$-catenin pathway plays an important role in tumorigenesis and cancer therapy [106]. We show that alcohol activates this pathway by inhibiting GSK3 $\beta$, which results in an increase in the migration/invasion of colon cancer cells [107]. However, the effect of alcohol on the GSK3 $\beta / \beta$-catenin pathway in the context of breast cancer aggressiveness needs to be further verified.

\subsection{The interaction between ROS and EGFR/ErbB2 signaling pathway in response to alcohol exposure}

As discussed above, both oxidative stress and EGFR/ErbB2-mediated cell signaling play an important role in alcohol-promoted aggressiveness of breast cancer. There is considerable interaction between oxidative stress and EGFR/ErbB2. ROS may either activate EGFR/ ErbB2 or directly target their down-stream signaling components [108-110]. This is supported by the evidence showing that alcohol stimulates the phosphorylation of EGFR and ErbB2 in mammary epithelial cells and breast cancer cells in a ROS-dependent manner [38, 66]. Cyanidin-3-glucoside (C3G), a potent antioxidant scavenges alcohol-induced ROS accumulation, blocks alcohol-induced phosphorylation of ErbB2 and the activation of downstream signaling proteins, such as cSrc, FAK and p130 Cas [38]. We further demonstrate that alcohol-induced ROS may activate MMP2 through the conventional PKC pathway in fibroblasts, which promotes the migration/invasion of breast cancer cells [40].

On the other hand, the status of EGFR/ErbB2 may also contribute to alcohol-induced oxidative stress. For example, it appears that high levels of ErbB2 make breast cancer cells and mammary epithelial cells more susceptible to alcohol-stimulated production of ROS [64]. In ErbB2 over-expressed cells, alcohol causes more intracellular accumulation of ${ }^{\circ} \mathrm{OH}$ radicals than in cells with low ErbB2 levels. The high levels of ROS in turn activates ErbB2mediated signaling as well as enzymes that contribute to aggressive behaviors of breast cancer cells, such as p38 $\gamma$, FAK, and MMP-2. The mechanisms underlying how ErbB2 contribute to alcohol-induced ROS production remain unclear.

\section{Conclusion, potential therapeutic targets, and future studies}

The experimental studies support the epidemiological observations that alcohol enhances the aggressiveness of breast cancer. However, the underlying mechanisms are complex and likely involved in multiple factors. Available evidence clearly demonstrates that ROS and EGFR/ErbB2 signaling play an important role in this process. Therefore, the approaches targeting oxidative stress and EGFR/ErbB2 signaling should be preferentially considered. 
First, scavenging alcohol-induced ROS using natural antioxidants is a practical strategy. For example, $\mathrm{C} 3 \mathrm{G}$, a potent natural antioxidant rich in many vegetables and fruits, proves to be very effective in alleviating alcohol-induced oxidative stress in breast cancer cells and neurons while it has a low cytotoxicity $[38,111]$. C3G has been proved to significantly attenuate alcohol-induced phosphorylation of ErbB2 and migration/invasion of breast cancer cells. Second, breast cancer cells with high levels of EGFR/ErbB2 appear to be more sensitive to alcohol. A further analysis of clinical data is necessary to establish the association of EGFR/ErbB2 status and the aggressiveness of breast cancer in the context of alcohol consumption. Reagents targeting these receptors, such as erlotinib (Tarceva) and trastuzumab (Herceptin), should be considered in patients who drink alcoholic beverages. Since alcohol specifically affects some signaling components and enzymes, such as $\mathrm{p} 38 \gamma$ and MMP2, drugs targeting these proteins may alleviate the aggressive behaviors associated with alcohol consumption. For example, selective inhibition of $\mathrm{p} 38 \gamma$ is sufficient to attenuate alcohol-stimulated CSC in breast cancer [33]. The inhibitors targeting MMP2 is also effective in blocking alcohol-stimulated invasion of breast cancer cells [41]. Third, targeting alcohol-promoted tumor angiogenesis may also be an important approach. For example, the growth factor VEGF and chemokine MCP-1 is involved in alcohol-promoted tumor angiogenesis [43, 44]; blocking VEGF and MCP-1-mediated signaling inhibits alcohol-induced tumor angiogenesis, growth and metastasis of breast cancer cells. Since alcohol affects multi-components/cascades involved in tumor progression and aggressiveness, future experimental studies may need to simultaneously target multiple components or cascades, which will likely yield more effective therapeutic outcomes particularly for alcoholic cancer patients. Finally, owing to the evidence that alcohol increases breast cancer progression, primary care givers should question each breast cancer patient about her alcohol intake. If the consumption is determined excessive, the patient should be informed about its consequences and recommend that alcohol intake be prohibited or reduced.

\section{Acknowledgments}

We thank Jacqueline Frank for reading this manuscript. This work is supported by grants from the National Institutes of Health (NIH) (AA017226 and AA015407).

\section{Abbreviations}

$\begin{array}{ll}\text { ADH } & \text { alcohol dehydrogenase } \\ \text { ALDH2 } & \text { aldehyde dehydrogenase } \\ \text { C3G } & \text { cyanidin-3-glucoside } \\ \text { CCL2 } & \text { chemokine (CC motif) ligand 2 } \\ \text { CCR2 } & \text { chemokine (CC motif) receptor 2 } \\ \text { CSC } & \text { cancer stem cells } \\ \text { CYP2E1 } & \text { cytochrome P450 2E1 }\end{array}$

Pharmacol Res. Author manuscript; available in PMC 2018 January 01. 


$\begin{array}{ll}\text { ECM } & \text { extracellular matrix } \\ \text { EGFR } & \text { epidermal growth factor receptor } \\ \text { EMT } & \text { epithelial-mesenchymal transition } \\ \text { MCP-1 } & \text { monocyte chemoattractant protein 1 } \\ \text { MMPs } & \text { matrix metalloproteinases } \\ \text { NOX } & \text { NADPH oxidase } \\ \text { ROS } & \text { reactive oxygen species } \\ \text { VEGF } & \text { vascular endothelial growth factor }\end{array}$

\section{References}

1. Becker S. A historic and scientific review of breast cancer: The next global healthcare challenge. Int J Gynaecol Obstet. 2015; 131(Suppl 1):S36-9. [PubMed: 26433503]

2. Oeffinger KC, Fontham ET, Etzioni R, Herzig A, Michaelson JS, Shih YC, Walter LC, Church TR, Flowers CR, LaMonte SJ, Wolf AM, DeSantis C, Lortet-Tieulent J, Andrews K, ManassaramBaptiste D, Saslow D, Smith RA, Brawley OW, Wender R. American Cancer S. Breast Cancer Screening for Women at Average Risk: 2015 Guideline Update From the American Cancer Society. Jama. 2015; 314(15):1599-614. [PubMed: 26501536]

3. Gerber B, Muller H, Reimer T, Krause A, Friese K. Nutrition and lifestyle factors on the risk of developing breast cancer. Breast cancer research and treatment. 2003; 79(2):265-76. [PubMed: 12825861]

4. Wogan GN, Hecht SS, Felton JS, Conney AH, Loeb LA. Environmental and chemical carcinogenesis. Semin Cancer Biol. 2004; 14(6):473-86. [PubMed: 15489140]

5. Rehm J. The risks associated with alcohol use and alcoholism. Alcohol research \& health : the journal of the National Institute on Alcohol Abuse and Alcoholism. 2011; 34(2):135-43. [PubMed: 22330211]

6. Hiatt RA. Alcohol consumption and breast cancer. Medical oncology and tumor pharmacotherapy. 1990; 7(2-3):143-51. [PubMed: 2146449]

7. Plant ML. Alcohol and breast cancer: a review. The International journal of the addictions. 1992; 27(2):107-28. [PubMed: 1544719]

8. Rosenberg L, Metzger LS, Palmer JR. Alcohol consumption and risk of breast cancer: a review of the epidemiologic evidence. Epidemiologic reviews. 1993; 15(1):133-44. [PubMed: 8405196]

9. Liu Y, Nguyen N, Colditz GA. Links between alcohol consumption and breast cancer: a look at the evidence. Womens Health (Lond). 2015; 11(1):65-77. [PubMed: 25581056]

10. Merten JW, Parker A, Williams A, King JL, Largo-Wight E, Osmani M. Cancer Risk Factor Knowledge Among Young Adults. J Cancer Educ. 2016

11. Cao Y, Giovannucci EL. Alcohol as a Risk Factor for Cancer. Semin Oncol Nurs. 2016; 32(3):32531. [PubMed: 27539286]

12. Connor J. Alcohol consumption as a cause of cancer. Addiction. 2016

13. Shield KD, Soerjomataram I, Rehm J. Alcohol Use and Breast Cancer: A Critical Review. Alcoholism, clinical and experimental research. 2016; 40(6):1166-81.

14. Ishii H, Kurose I, Kato S. Pathogenesis of alcoholic liver disease with particular emphasis on oxidative stress. Journal of gastroenterology and hepatology. 1997; 12(9-10):S272-82. [PubMed: 9407347]

15. Jeong KS, Soh Y, Jeng J, Felder MR, Hardwick JP, Song BJ. Cytochrome P450 2E1 (CYP2E1)dependent production of a $37-\mathrm{kDa}$ acetaldehyde-protein adduct in the rat liver. Archives of biochemistry and biophysics. 2000; 384(1):81-7. [PubMed: 11147839] 
16. Nakamura K, Iwahashi K, Furukawa A, Ameno K, Kinoshita H, Ijiri I, Sekine Y, Suzuki K, Iwata Y, Minabe Y, Mori N. Acetaldehyde adducts in the brain of alcoholics. Archives of toxicology. 2003; 77(10):591-3. [PubMed: 14574447]

17. Dumitrescu RG, Shields PG. The etiology of alcohol-induced breast cancer. Alcohol. 2005; 35(3): 213-25. [PubMed: 16054983]

18. Svegliati-Baroni G, Baraona E, Rosman AS, Lieber CS. Collagen-acetaldehyde adducts in alcoholic and nonalcoholic liver diseases. Hepatology. 1994; 20(1 Pt 1):111-8. [PubMed: 7912686]

19. Castro GD, Castro JA. Alcohol drinking and mammary cancer: Pathogenesis and potential dietary preventive alternatives. World J Clin Oncol. 2014; 5(4):713-29. [PubMed: 25300769]

20. Fan S, Meng Q, Gao B, Grossman J, Yadegari M, Goldberg ID, Rosen EM. Alcohol stimulates estrogen receptor signaling in human breast cancer cell lines. Cancer research. 2000; 60(20):56359. [PubMed: 11059753]

21. Singletary KW, Frey RS, Yan W. Effect of ethanol on proliferation and estrogen receptor-alpha expression in human breast cancer cells. Cancer letters. 2001; 165(2):131-7. [PubMed: 11275361]

22. Izevbigie EB, Ekunwe SI, Jordan J, Howard CB. Ethanol modulates the growth of human breast cancer cells in vitro. Experimental biology and medicine. 2002; 227(4):260-5. [PubMed: 11910048]

23. Etique N, Chardard D, Chesnel A, Merlin JL, Flament S, Grillier-Vuissoz I. Ethanol stimulates proliferation, ERa and aromatase expression in MCF-7 human breast cancer cells. International journal of molecular medicine. 2004; 13(1):149-55. [PubMed: 14654987]

24. Varela-Rey M, Woodhoo A, Martinez-Chantar ML, Mato JM, Lu SC. Alcohol, DNA methylation, and cancer. Alcohol Res. 2013; 35(1):25-35. [PubMed: 24313162]

25. Wang XD. Alcohol, vitamin A, and cancer. Alcohol. 2005; 35(3):251-8. [PubMed: 16054987]

26. Cohick WS, Crismale-Gann C, Stires H, Katz TA. Fetal alcohol exposure and mammary tumorigenesis in offspring: role of the estrogen and insulin-like growth factor systems. Advances in experimental medicine and biology. 2015; 815:403-24. [PubMed: 25427921]

27. Garcia-Quiroz J, Garcia-Becerra R, Lara-Sotelo G, Avila E, Lopez S, Santos-Martinez N, Halhali A, Ordaz-Rosado D, Barrera D, Olmos-Ortiz A, Ibarra-Sanchez MJ, Esparza-Lopez J, Larrea F, Diaz L. Chronic moderate ethanol intake differentially regulates vitamin D hydroxylases gene expression in kidneys and xenografted breast cancer cells in female mice. The Journal of steroid biochemistry and molecular biology. 2016

28. Weiss HA, Brinton LA, Brogan D, Coates RJ, Gammon MD, Malone KE, Schoenberg JB, Swanson CA. Epidemiology of in situ and invasive breast cancer in women aged under 45. British journal of cancer. 1996; 73(10):1298-305. [PubMed: 8630296]

29. Vaeth PA, Satariano WA. Alcohol consumption and breast cancer stage at diagnosis. Alcoholism, clinical and experimental research. 1998; 22(4):928-34.

30. O'Brien KM, Sun J, Sandler DP, DeRoo LA, Weinberg CR. Risk factors for young-onset invasive and in situ breast cancer. Cancer causes \& control : CCC. 2015; 26(12):1771-8. [PubMed: 26407954]

31. Williams LA, Olshan AF, Tse CK, Bell ME, Troester MA. Alcohol intake and invasive breast cancer risk by molecular subtype and race in the Carolina Breast Cancer Study. Cancer causes \& control : CCC. 2016; 27(2):259-69. [PubMed: 26705260]

32. Xu M, Wang S, Ren Z, Frank JA, Yang XH, Zhang Z, Ke ZJ, Shi X, Luo J. Chronic ethanol exposure enhances the aggressiveness of breast cancer: the role of p38 $\gamma$. Oncotarget. 2016; 7(3): 3489-505. [PubMed: 26655092]

33. Xu M, Ren Z, Wang X, Comer A, Frank JA, Ke ZJ, Huang Y, Zhang Z, Shi X, Wang S, Luo J. ErbB2 and p38 $\beta$ MAPK mediate alcohol-induced increase in breast cancer stem cells and metastasis. Molecular cancer. 2016; 15(1):52. [PubMed: 27416801]

34. Zhao M, Howard EW, Parris AB, Guo Z, Zhao Q, Yang X. Alcohol promotes migration and invasion of triple-negative breast cancer cells through activation of p38 MAPK and JNK. Molecular carcinogenesis. 2016

35. Luo J, Miller MW. Ethanol enhances erbB-mediated migration of human breast cancer cells in culture. Breast cancer research and treatment. 2000; 63(1):61-9. [PubMed: 11079160] 
36. Meng Q, Gao B, Goldberg ID, Rosen EM, Fan S. Stimulation of cell invasion and migration by alcohol in breast cancer cells. Biochemical and biophysical research communications. 2000; 273(2):448-53. [PubMed: 10873626]

37. Xu M, Bower KA, Chen G, Shi X, Dong Z, Ke Z, Luo J. Ethanol enhances the interaction of breast cancer cells over-expressing ErbB2 with fibronectin. Alcoholism, clinical and experimental research. 2010; 34(5):751-60.

38. Xu M, Bower KA, Wang S, Frank JA, Chen G, Ding M, Wang S, Shi X, Ke Z, Luo J. Cyanidin-3glucoside inhibits ethanol-induced invasion of breast cancer cells overexpressing ErbB2. Molecular cancer. 2010; 9:285. [PubMed: 21034468]

39. Qian Y, Luo J, Leonard SS, Harris GK, Millecchia L, Flynn DC, Shi X. Hydrogen peroxide formation and actin filament reorganization by $\mathrm{Cdc} 42$ are essential for ethanol-induced in vitro angiogenesis. The Journal of biological chemistry. 2003; 278(18):16189-97. [PubMed: 12598535]

40. Aye MM, Ma C, Lin H, Bower KA, Wiggins RC, Luo J. Ethanol-induced in vitro invasion of breast cancer cells: the contribution of MMP-2 by fibroblasts. International journal of cancer. 2004; 112(5):738-46. [PubMed: 15386367]

41. Ke Z, Lin H, Fan Z, Cai TQ, Kaplan RA, Ma C, Bower KA, Shi X, Luo J. MMP-2 mediates ethanol-induced invasion of mammary epithelial cells over-expressing ErbB2. International journal of cancer. 2006; 119(1):8-16. [PubMed: 16450376]

42. Wong AW, Paulson QX, Hong J, Stubbins RE, Poh K, Schrader E, Nunez NP. Alcohol promotes breast cancer cell invasion by regulating the Nm23-ITGA5 pathway. J Exp Clin Cancer Res. 2011; 30:75. [PubMed: 21838876]

43. Wang S, Xu M, Li F, Wang X, Bower KA, Frank JA, Lu Y, Chen G, Zhang Z, Ke Z, Shi X, Luo J. Ethanol promotes mammary tumor growth and angiogenesis: the involvement of chemoattractant factor MCP-1. Breast cancer research and treatment. 2012; 133(3):1037-48. [PubMed: 22160640]

44. Lu Y, Ni F, Xu M, Yang J, Chen J, Chen Z, Wang X, Luo J, Wang S. Alcohol promotes mammary tumor growth through activation of VEGF-dependent tumor angiogenesis. Oncol Lett. 2014; 8(2): 673-678. [PubMed: 25009649]

45. Narayanan PD, Nandabalan SK, Baddireddi LS. Role of STAT3 Phosphorylation in EthanolMediated Proliferation of Breast Cancer Cells. J Breast Cancer. 2016; 19(2):122-32. [PubMed: 27382387]

46. Stallings-Mann M, Radisky D. Matrix metalloproteinase-induced malignancy in mammary epithelial cells. Cells Tissues Organs. 2007; 185(1-3):104-10. [PubMed: 17587815]

47. Etique N, Grillier-Vuissoz I, Flament S. Ethanol stimulates the secretion of matrix metalloproteinases 2 and 9 in MCF-7 human breast cancer cells. Oncol Rep. 2006; 15(3):603-8. [PubMed: 16465419]

48. Xu M, Chen G, Fu W, Liao M, Frank JA, Bower KA, Fang S, Zhang Z, Shi X, Luo J. Ethanol disrupts vascular endothelial barrier: implication in cancer metastasis. Toxicological sciences : an official journal of the Society of Toxicology. 2012; 127(1):42-53. [PubMed: 22331491]

49. Forsyth CB, Tang Y, Shaikh M, Zhang L, Keshavarzian A. Alcohol stimulates activation of Snail, epidermal growth factor receptor signaling, and biomarkers of epithelial-mesenchymal transition in colon and breast cancer cells. Alcoholism, clinical and experimental research. 2010; 34(1):1931 .

50. Gu JW, Elam J, Sartin A, Li W, Roach R, Adair TH. Moderate levels of ethanol induce expression of vascular endothelial growth factor and stimulate angiogenesis. American journal of physiology. Regulatory, integrative and comparative physiology. 2001; 281(1):R365-72.

51. Tan W, Bailey AP, Shparago M, Busby B, Covington J, Johnson JW, Young E, Gu JW. Chronic alcohol consumption stimulates VEGF expression, tumor angiogenesis and progression of melanoma in mice. Cancer biology \& therapy. 2007; 6(8):1211-7. [PubMed: 17660711]

52. Ajani JA, Song S, Hochster HS, Steinberg IB. Cancer stem cells: the promise and the potential. Seminars in oncology. 2015; 42(Suppl 1):S3-17.

53. Yang F, Xu J, Tang L, Guan X. Breast cancer stem cell: the roles and therapeutic implications. Cellular and molecular life sciences : CMLS. 2016

54. Hecht F, Pessoa CF, Gentile LB, Rosenthal D, Carvalho DP, Fortunato RS. The role of oxidative stress on breast cancer development and therapy. Tumour biology : the journal of the International 
Society for Oncodevelopmental Biology and Medicine. 2016; 37(4):4281-91. [PubMed: 26815507]

55. Hoek JB, Cahill A, Pastorino JG. Alcohol and mitochondria: a dysfunctional relationship. Gastroenterology. 2002; 122(7):2049-63. [PubMed: 12055609]

56. Wang X, Ke Z, Chen G, Xu M, Bower KA, Frank JA, Zhang Z, Shi X, Luo J. Cdc42-dependent activation of NADPH oxidase is involved in ethanol-induced neuronal oxidative stress. PloS one. 2012; 7(5):e38075. [PubMed: 22662267]

57. Page S, Powell D, Benboubetra M, Stevens CR, Blake DR, Selase F, Wolstenholme AJ, Harrison R. Xanthine oxidoreductase in human mammary epithelial cells: activation in response to inflammatory cytokines. Biochimica et biophysica acta. 1998; 1381(2):191-202. [PubMed: 9685639]

58. Wright RM, McManaman JL, Repine JE. Alcohol-induced breast cancer: a proposed mechanism. Free radical biology \& medicine. 1999; 26(3-4):348-54. [PubMed: 9895226]

59. Iscan M, Klaavuniemi T, Coban T, Kapucuoglu N, Pelkonen O, Raunio H. The expression of cytochrome $\mathrm{P} 450$ enzymes in human breast tumours and normal breast tissue. Breast cancer research and treatment. 2001; 70(1):47-54. [PubMed: 11767004]

60. El-Rayes BF, Ali S, Heilbrun LK, Lababidi S, Bouwman D, Visscher D, Philip PA. Cytochrome p450 and glutathione transferase expression in human breast cancer. Clinical cancer research : an official journal of the American Association for Cancer Research. 2003; 9(5):1705-9. [PubMed: 12738724]

61. Kapucuoglu N, Coban T, Raunio H, Pelkonen O, Edwards RJ, Boobis AR, Iscan M. Immunohistochemical demonstration of the expression of CYP2E1 in human breast tumour and non-tumour tissues. Cancer letters. 2003; 196(2):153-9. [PubMed: 12860273]

62. Triano EA, Slusher LB, Atkins TA, Beneski JT, Gestl SA, Zolfaghari R, Polavarapu R, Frauenhoffer E, Weisz J. Class I alcohol dehydrogenase is highly expressed in normal human mammary epithelium but not in invasive breast cancer: implications for breast carcinogenesis. Cancer research. 2003; 63(12):3092-100. [PubMed: 12810634]

63. Boudreau HE, Casterline BW, Rada B, Korzeniowska A, Leto TL. Nox4 involvement in TGF-beta and SMAD3-driven induction of the epithelial-to-mesenchymal transition and migration of breast epithelial cells. Free radical biology \& medicine. 2012; 53(7):1489-99. [PubMed: 22728268]

64. Ma C, Lin H, Leonard SS, Shi X, Ye J, Luo J. Overexpression of ErbB2 enhances ethanolstimulated intracellular signaling and invasion of human mammary epithelial and breast cancer cells in vitro. Oncogene. 2003; 22(34):5281-90. [PubMed: 12917629]

65. Sanchez-Alvarez R, Martinez-Outschoorn UE, Lin Z, Lamb R, Hulit J, Howell A, Sotgia F, Rubin E, Lisanti MP. Ethanol exposure induces the cancer-associated fibroblast phenotype and lethal tumor metabolism: implications for breast cancer prevention. Cell Cycle. 2013; 12(2):289-301. [PubMed: 23257780]

66. Leon-Buitimea A, Rodriguez-Fragoso L, Lauer FT, Bowles H, Thompson TA, Burchiel SW. Ethanol-induced oxidative stress is associated with EGF receptor phosphorylation in MCF-10A cells overexpressing CYP2E1. Toxicol Lett. 2012; 209(2):161-5. [PubMed: 22222162]

67. Barnes SL, Singletary KW, Frey R. Ethanol and acetaldehyde enhance benzo[a]pyrene-DNA adduct formation in human mammary epithelial cells. Carcinogenesis. 2000; 21(11):2123-8. [PubMed: 11062178]

68. Luo J. Role of matrix metalloproteinase-2 in ethanol-induced invasion by breast cancer cells. Journal of gastroenterology and hepatology. 2006; 21(Suppl 3):S65-8. [PubMed: 16958676]

69. Cichon MA, Radisky DC. ROS-induced epithelial-mesenchymal transition in mammary epithelial cells is mediated by NF-kB-dependent activation of Snail. Oncotarget. 2014; 5(9):2827-38. [PubMed: 24811539]

70. Karicheva O, Rodriguez-Vargas JM, Wadier N, Martin-Hernandez K, Vauchelles R, Magroun N, Tissier A, Schreiber V, Dantzer F. PARP3 controls TGF $\beta$ and ROS driven epithelial-tomesenchymal transition and stemness by stimulating a TG2-Snail-E-cadherin axis. Oncotarget. 2016

71. Cai T, Fassina G, Morini M, Aluigi MG, Masiello L, Fontanini G, D'Agostini F, De Flora S, Noonan DM, Albini A. N-acetylcysteine inhibits endothelial cell invasion and angiogenesis. 
Laboratory investigation; a journal of technical methods and pathology. 1999; 79(9):1151-9. [PubMed: 10496534]

72. Wheeler MD, Smutney OM, Samulski RJ. Secretion of extracellular superoxide dismutase from muscle transduced with recombinant adenovirus inhibits the growth of B16 melanomas in mice. Molecular cancer research : MCR. 2003; 1(12):871-81. [PubMed: 14573788]

73. Al-Shabrawey M, Bartoli M, El-Remessy AB, Platt DH, Matragoon S, Behzadian MA, Caldwell $\mathrm{RW}$, Caldwell RB. Inhibition of NAD $(\mathrm{P}) \mathrm{H}$ oxidase activity blocks vascular endothelial growth factor overexpression and neovascularization during ischemic retinopathy. The American journal of pathology. 2005; 167(2):599-607. [PubMed: 16049343]

74. Kim YM, Kim KE, Koh GY, Ho YS, Lee KJ. Hydrogen peroxide produced by angiopoietin-1 mediates angiogenesis. Cancer research. 2006; 66(12):6167-74. [PubMed: 16778190]

75. Ruef J, Hu ZY, Yin LY, Wu Y, Hanson SR, Kelly AB, Harker LA, Rao GN, Runge MS, Patterson C. Induction of vascular endothelial growth factor in balloon-injured baboon arteries. A novel role for reactive oxygen species in atherosclerosis. Circulation research. 1997; 81(1):24-33. [PubMed: 9201024]

76. Ushio-Fukai M, Tang Y, Fukai T, Dikalov SI, Ma Y, Fujimoto M, Quinn MT, Pagano PJ, Johnson C, Alexander RW. Novel role of gp91(phox)-containing NAD(P)H oxidase in vascular endothelial growth factor-induced signaling and angiogenesis. Circulation research. 2002; 91(12):1160-7. [PubMed: 12480817]

77. Bordon Y. A new vein of TLR biology. Nature reviews. Immunology. 2010; 10(11):748.

78. Okuno Y, Nakamura-Ishizu A, Otsu K, Suda T, Kubota Y. Pathological neoangiogenesis depends on oxidative stress regulation by ATM. Nature medicine. 2012; 18(8):1208-16.

79. Wang F, Yang JL, Yu KK, Xu M, Xu YZ, Chen L, Lu YM, Fang HS, Wang XY, Hu ZQ, Li FF, Kan L, Luo J, Wang SY. Activation of the NF-kB pathway as a mechanism of alcohol enhanced progression and metastasis of human hepatocellular carcinoma. Molecular cancer. 2015; 14:10. [PubMed: 25622857]

80. van Wetering S, van Buul JD, Quik S, Mul FP, Anthony EC, ten Klooster JP, Collard JG, Hordijk PL. Reactive oxygen species mediate Rac-induced loss of cell-cell adhesion in primary human endothelial cells. Journal of cell science. 2002; 115(Pt 9):1837-46. [PubMed: 11956315]

81. Yamaoka-Tojo M, Tojo T, Kim HW, Hilenski L, Patrushev NA, Zhang L, Fukai T, Ushio-Fukai M. IQGAP1 mediates VE-cadherin-based cell-cell contacts and VEGF signaling at adherence junctions linked to angiogenesis. Arteriosclerosis, thrombosis, and vascular biology. 2006; 26(9): 1991-7.

82. Monaghan-Benson E, Burridge K. The regulation of vascular endothelial growth factor-induced microvascular permeability requires Rac and reactive oxygen species. The Journal of biological chemistry. 2009; 284(38):25602-11. [PubMed: 19633358]

83. Davis NM, Sokolosky M, Stadelman K, Abrams SL, Libra M, Candido S, Nicoletti F, Polesel J, Maestro R, D'Assoro A, Drobot L, Rakus D, Gizak A, Laidler P, Dulinska-Litewka J, Basecke J, Mijatovic S, Maksimovic-Ivanic D, Montalto G, Cervello M, Fitzgerald TL, Demidenko Z, Martelli AM, Cocco L, Steelman LS, McCubrey JA. Deregulation of the EGFR/PI3K/PTEN/Akt/ mTORC1 pathway in breast cancer: possibilities for therapeutic intervention. Oncotarget. 2014; 5(13):4603-50. [PubMed: 25051360]

84. Sirkisoon SR, Carpenter RL, Rimkus T, Miller L, Metheny-Barlow L, Lo HW. EGFR and HER2 signaling in breast cancer brain metastasis. Front Biosci (Elite Ed). 2016; 8:245-63. [PubMed: 26709660]

85. Lohrisch C, Piccart M. An overview of HER2. Seminars in oncology. 2001; 28(6 Suppl 18):3-11.

86. Perou CM, Sorlie T, Eisen MB, van de Rijn M, Jeffrey SS, Rees CA, Pollack JR, Ross DT, Johnsen H, Akslen LA, Fluge O, Pergamenschikov A, Williams C, Zhu SX, Lonning PE, Borresen-Dale AL, Brown PO, Botstein D. Molecular portraits of human breast tumours. Nature. 2000; 406(6797):747-52. [PubMed: 10963602]

87. Weigelt B, Hu Z, He X, Livasy C, Carey LA, Ewend MG, Glas AM, Perou CM, Van't Veer LJ. Molecular portraits and 70-gene prognosis signature are preserved throughout the metastatic process of breast cancer. Cancer research. 2005; 65(20):9155-8. [PubMed: 16230372] 
88. Moasser MM. The oncogene HER2: its signaling and transforming functions and its role in human cancer pathogenesis. Oncogene. 2007; 26(45):6469-87. [PubMed: 17471238]

89. Wilson KJ, Mill C, Lambert S, Buchman J, Wilson TR, Hernandez-Gordillo V, Gallo RM, Ades LM, Settleman J, Riese DJ 2nd. EGFR ligands exhibit functional differences in models of paracrine and autocrine signaling. Growth Factors. 2012; 30(2):107-16. [PubMed: 22260327]

90. Kenney NJ, Smith GH, Rosenberg K, Cutler ML, Dickson RB. Induction of ductal morphogenesis and lobular hyperplasia by amphiregulin in the mouse mammary gland. Cell growth \& differentiation : the molecular biology journal of the American Association for Cancer Research. 1996; 7(12):1769-81. [PubMed: 8959346]

91. Kenney NJ, Bowman A, Korach KS, Barrett JC, Salomon DS. Effect of exogenous epidermal-like growth factors on mammary gland development and differentiation in the estrogen receptor- $a$ knockout (ERKO) mouse. Breast cancer research and treatment. 2003; 79(2):161-73. [PubMed: $12825851]$

92. Ding Q, Xia W, Liu JC, Yang JY, Lee DF, Xia J, Bartholomeusz G, Li Y, Pan Y, Li Z, Bargou RC, Qin J, Lai CC, Tsai FJ, Tsai CH, Hung MC. Erk associates with and primes GSK-3 $\beta$ for its inactivation resulting in upregulation of $\beta$-catenin. Molecular cell. 2005; 19(2):159-70. [PubMed: 16039586]

93. Biswas DK, Iglehart JD. Linkage between EGFR family receptors and nuclear factor kB (NF-kB) signaling in breast cancer. Journal of cellular physiology. 2006; 209(3):645-52. [PubMed: 17001676]

94. Mill CP, Chester JA, Riese DJ 2nd. EGFR may couple moderate alcohol consumption to increased breast cancer risk. Breast cancer. 2009; 1:31-8. [PubMed: 24367161]

95. La Rocca G, Pucci-Minafra I, Marrazzo A, Taormina P, Minafra S. Zymographic detection and clinical correlations of MMP-2 and MMP-9 in breast cancer sera. British journal of cancer. 2004; 90(7):1414-21. [PubMed: 15054465]

96. Ma Z, Blackwelder AJ, Lee H, Zhao M, Yang X. In Utero exposure to low-dose alcohol induces reprogramming of mammary development and tumor risk in MMTV-erbB-2 transgenic mice. International journal of molecular sciences. 2015; 16(4):7655-71. [PubMed: 25853264]

97. Rosenthal DT, Iyer H, Escudero S, Bao L, Wu Z, Ventura AC, Kleer CG, Arruda EM, Garikipati K, Merajver SD. p38gamma promotes breast cancer cell motility and metastasis through regulation of RhoC GTPase, cytoskeletal architecture, and a novel leading edge behavior. Cancer research. 2011; 71(20):6338-49. [PubMed: 21862636]

98. Etienne-Manneville S, Manneville JB, Nicholls S, Ferenczi MA, Hall A. Cdc42 and Par6-PKCzeta regulate the spatially localized association of Dlg1 and APC to control cell polarization. The Journal of cell biology. 2005; 170(6):895-901. [PubMed: 16157700]

99. O'Neill AK, Gallegos LL, Justilien V, Garcia EL, Leitges M, Fields AP, Hall RA, Newton AC. Protein kinase $\mathrm{Ca}$ promotes cell migration through a PDZ-dependent interaction with its novel substrate discs large homolog 1 (DLG1). The Journal of biological chemistry. 2011; 286(50): 43559-68. [PubMed: 22027822]

100. Ikoma T, Takahashi T, Nagano S, Li YM, Ohno Y, Ando K, Fujiwara T, Fujiwara H, Kosai K. A definitive role of RhoC in metastasis of orthotopic lung cancer in mice. Clinical cancer research : an official journal of the American Association for Cancer Research. 2004; 10(3):1192-200. [PubMed: 14871999]

101. Srivastava S, Ramdass B, Nagarajan S, Rehman M, Mukherjee G, Krishna S. Notch1 regulates the functional contribution of RhoC to cervical carcinoma progression. British journal of cancer. 2010; 102(1):196-205. [PubMed: 19953094]

102. Zhao Y, Zong ZH, Xu HM. RhoC expression level is correlated with the clinicopathological characteristics of ovarian cancer and the expression levels of ROCK-I, VEGF, and MMP9. Gynecologic oncology. 2010; 116(3):563-71. [PubMed: 20022093]

103. Benlimame N, He Q, Jie S, Xiao D, Xu YJ, Loignon M, Schlaepfer DD, Alaoui-Jamali MA. FAK signaling is critical for ErbB-2/ErbB-3 receptor cooperation for oncogenic transformation and invasion. The Journal of cell biology. 2005; 171(3):505-16. [PubMed: 16275754] 
104. Aikawa R, Nagai T, Kudoh S, Zou Y, Tanaka M, Tamura M, Akazawa H, Takano H, Nagai R, Komuro I. Integrins play a critical role in mechanical stress-induced p38 MAPK activation. Hypertension. 2002; 39(2):233-8. [PubMed: 11847190]

105. Cox BD, Natarajan M, Stettner MR, Gladson CL. New concepts regarding focal adhesion kinase promotion of cell migration and proliferation. Journal of cellular biochemistry. 2006; 99(1):3552. [PubMed: 16823799]

106. Luo J. Glycogen synthase kinase $3 \beta$ (GSK3 $\beta$ ) in tumorigenesis and cancer chemotherapy. Cancer letters. 2009; 273(2):194-200. [PubMed: 18606491]

107. Xu M, Wang S, Qi Y, Chen L, Frank JA, Yang XH, Zhang Z, Shi X, Luo J. Role of MCP-1 in alcohol-induced aggressiveness of colorectal cancer cells. Molecular carcinogenesis. 2016; 55(5): 1002-11. [PubMed: 26014148]

108. Gupta P, Srivastava SK. Antitumor activity of phenethyl isothiocyanate in HER2-positive breast cancer models. BMC Med. 2012; 10:80. [PubMed: 22824293]

109. Kimura K, Takada M, Ishii T, Tsuji-Naito K, Akagawa M. Pyrroloquinoline quinone stimulates epithelial cell proliferation by activating epidermal growth factor receptor through redox cycling. Free radical biology \& medicine. 2012; 53(6):1239-51. [PubMed: 22824864]

110. Mohan N, Shen Y, Endo Y, ElZarrad MK, Wu WJ. Trastuzumab, but Not Pertuzumab, Dysregulates HER2 Signaling to Mediate Inhibition of Autophagy and Increase in Reactive Oxygen Species Production in Human Cardiomyocytes. Mol Cancer Ther. 2016; 15(6):1321-31. [PubMed: 27197303]

111. Ke Z, Liu Y, Wang X, Fan Z, Chen G, Xu M, Bower KA, Frank JA, Ou X, Shi X, Luo J. Cyanidin-3-glucoside ameliorates ethanol neurotoxicity in the developing brain. J Neurosci Res. 2011; 89(10):1676-84. [PubMed: 21671257] 
A

\begin{tabular}{|c|c|c|c|c|c|c|c|}
\cline { 3 - 8 } \multicolumn{2}{c|}{} & \multicolumn{3}{c|}{ Lung Metastasis } & \multicolumn{3}{c|}{ Colon Metastasis } \\
\cline { 2 - 8 } & Total Mice & Positive & Negative & $\%$ & Positive & Negative & $\%$ \\
\hline Control & 12 & 2 & 10 & 16.7 & 0 & 12 & 0 \\
\hline EtOH & 11 & 9 & 2 & 81.8 & 5 & 6 & 45.4 \\
\hline & & & & $p=0.003$ & & & $p=0.014$ \\
\hline
\end{tabular}

B

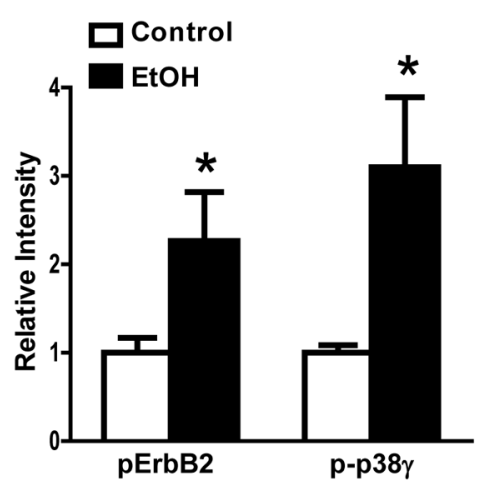

Figure 1.

Alcohol promotes cancer metastasis and the activation of ErbB2. A: FVB MMTV Neu mice were fed with liquid diet containing ethanol ( 0 or $6.7 \%$ ). After tumors reached a maximal diameter of $20 \mathrm{~mm}$, mice were sacrificed and analyzed for tumor metastasis. Alcohol consumption significantly increased the metastases in the lung and colon. B: After alcohol exposure, the mammary tumor tissues were assessed for the expression of phosphorylated ErbB2 (pErbB2) and p38 $\gamma$ MAPK (p-p38 $\gamma$ ) by immunoblotting. The relative levels of pErbB2 and p-p38 $\gamma$ were quantified and normalized to the loading control. * denotes significant difference from control groups $(\mathrm{p}<0.05)$. Alcohol consumption significantly increased the phosphorylation of ErbB2 and p38 ([33]. 
A

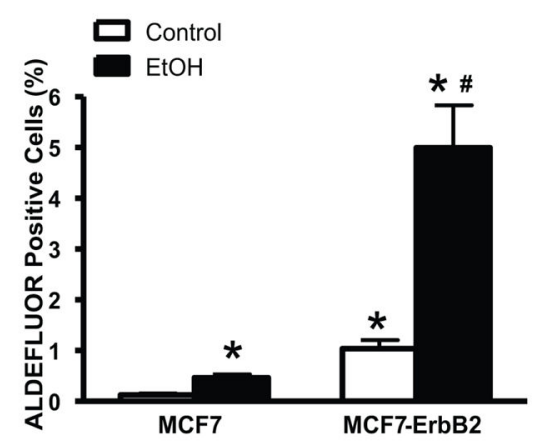

C

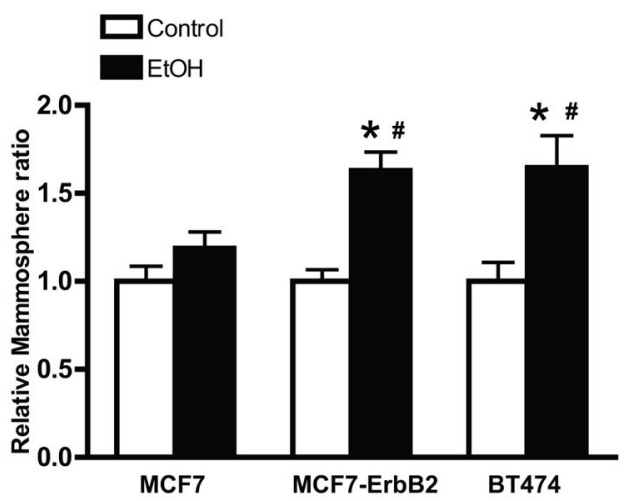

D

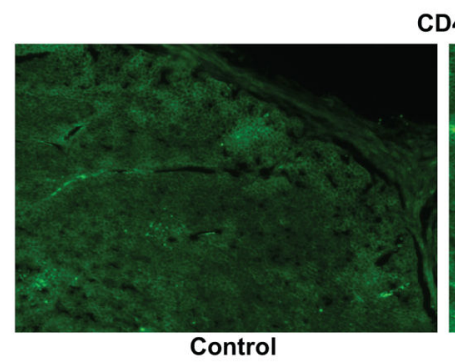

CD44

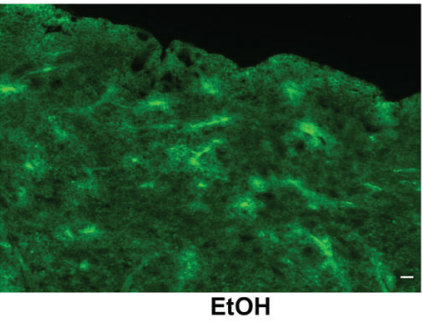

B
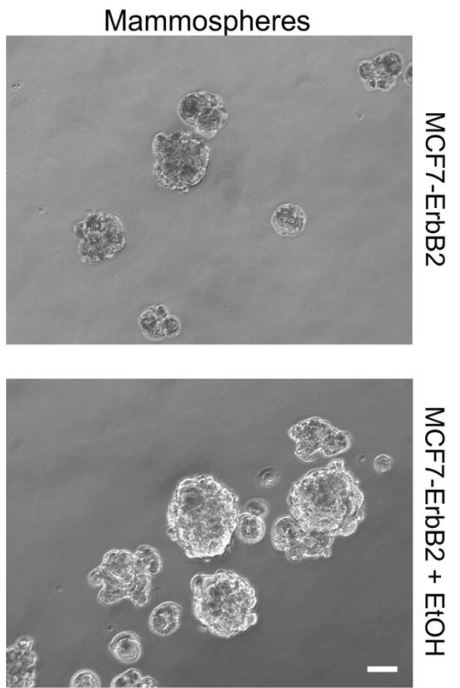

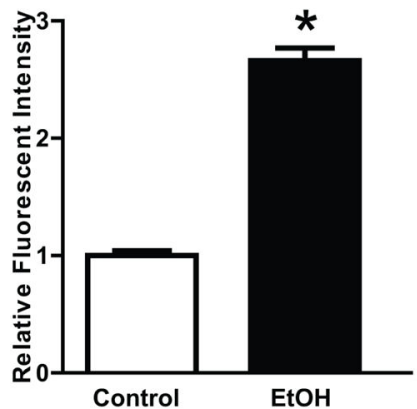

Figure 2.

Alcohol increases the cancer stem-like cell (CSC) population. A: Human breast cancer cell lines MCF7 or MCF7 overexpressing ErbB2 cells (MCF7-ErbB2) were exposed to alcohol ( 0 or $100 \mathrm{mg} / \mathrm{dl}$ ) for 10 days, and then evaluated for CSCs by the ALDEFLUOR assay. * denotes significant difference from respective control groups. \# denotes significant difference from alcohol-treated MCF7 cells. B: MCF7-ErbB2 cells were exposed to alcohol $(0,100 \mathrm{mg} / \mathrm{dl})$ for 10 days and then mammosphere formation was evaluated under the microscope. C: MCF7, MCF7-ErbB2 or BT474 cells were exposed to alcohol (0, 100 $\mathrm{mg} / \mathrm{dl}$ ) for 10 days. The number of mammospheres was determined. * denotes significant difference from respective control groups. \# denotes significant difference from alcoholtreated MCF7 cells. D: FVB MMTV Neu mice were fed with a liquid diet containing 
ethanol ( 0 or $6.7 \%)$. After alcohol exposure, the mammary tumor tissues were assessed for the expression of CD44. * denotes significant difference from respective control groups.

Alcohol significantly increased CSC population in vitro and in vivo [33]. 
A

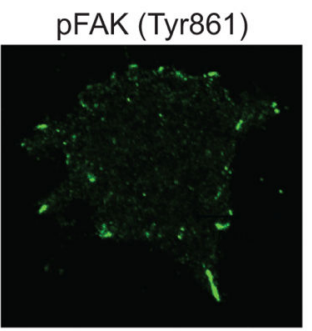

pErbB2 (Tyr1248)

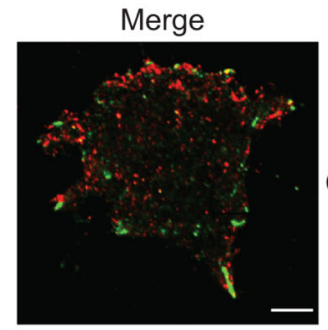

Control
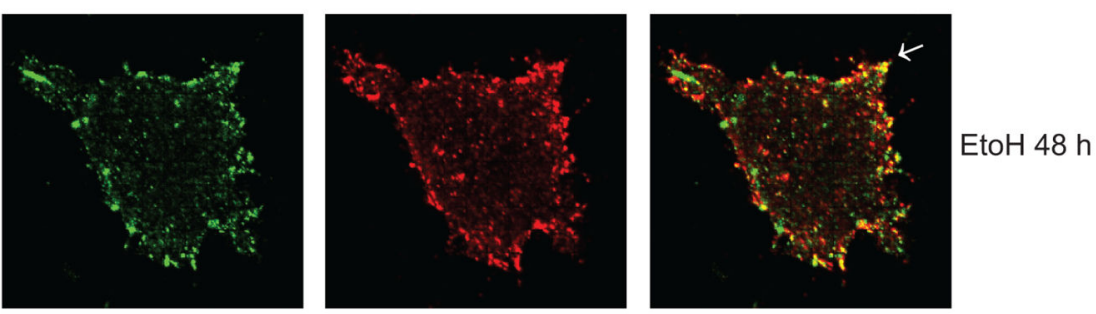

B

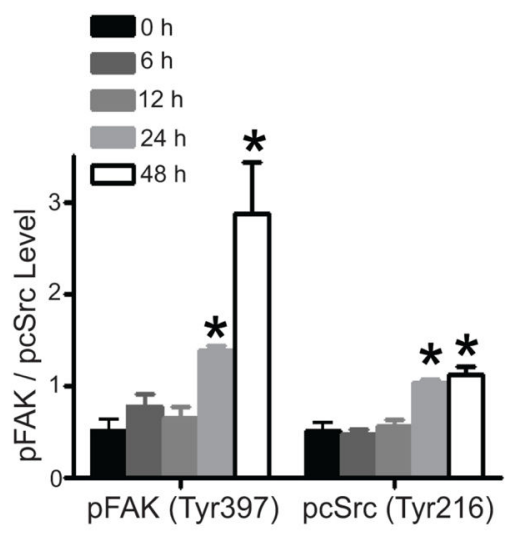

Figure 3.

Alcohol stimulates the phosphorylation of ErbB2, FAK and cSrc. A: MCF7-ErbB2 cells were pretreated with alcohol for 48 hours and plated to fibronectin-coated coverslips, allowing attachment for 1 hour. Phosphorylation of FAK (Tyr861) and ErbB2 (Tyr1248) was detected with immunofluorescent staining. Arrows indicate the co-localization of pErbB2 and pFAK. B: MCF7-ErbB2 cells were pretreated with alcohol for 6-48 hours, and allowed to attach for 3 hours. Cell lysates were collected and analyzed for the phosphorylation of FAK and cSrc with immunoblotting. The relative levels of pFAK and pcSrc were quantified and normalized to the expression of FAK and cSrc, respectively. * denotes significant difference from respective control groups. Alcohol significantly increased the phosphorylation of ErbB2, FAK and cSrc [37]. 